\title{
Pilot study of the influence of a communicator's speech characteristics on a recipient's willingness to maintain interaction in cross-cultural online communication
}

\author{
Nadezhda S. Rudenko ${ }^{{ }^{*}}$, Svetlana G. Krylova ${ }^{\mathrm{b}}$ \\ ${ }^{a}$ Chair of English Language, Teaching Methods and Translation, Ural State Pedagogical University, \\ Ekaterinburg, Russia \\ ${ }^{\mathrm{b}}$ Social Psychology, Conflictology and Management Chair, Ural State Pedagogical University, \\ Ekaterinburg, Russia
}

${ }^{\star}$ Corresponding author. E-mail: nadezhda.s.rudenko@gmail.com

\begin{abstract}
The success of cross-cultural online communication in an academic environment is defined by the degree of student involvement in such an interaction. The authors' experience testifies that a number of objective, language, and psychological factors may decrease the activeness of these interactions, and as a result learning may not be effective for students in these types of cross-cultural interactions. Among such factors the current article investigates the influence of a communicator's speech peculiarities on a recipient's willingness to maintain interaction in native-to-nonnative, written online communication in the English language. The study was aimed at verifying a hypothesis about the influence of Russian communicants' speech characteristics on American communicants' willingness to maintain conversations. The research method chosen was content analysis. Thematic chats involving Russian and American students participating in the Global Understanding course were analyzed. The results of the content analysis allowed us to distinguish certain Russian communicants' written speech characteristics, such as the prevalence of language and grammar mistakes, the degree of vocabulary richness, and the use of complex sentences. Significant correlations were discovered between the American communicants' willingness to maintain conversations and the number of mistakes, indicators of lexical richness and scarcity in Russian communicants' utterances. Language and speech mistakes as well as the quantity of words in the utterances of micro themes had the highest number of significant correlations with indicators of the willingness to maintain conversations. The first factor, language and speech mistakes, decreased the willingness to maintain conversations, whereas the second factor, the number of words in Russian students' utterances, increased such willingness.
\end{abstract}

Keywords: intercultural communicative competence, cross-cultural online communication, written communication, language and speech mistakes, willingness to maintain interaction 


\section{Introduction}

The third generation of Russian Federal State standards for higher professional education include intercultural communicative competencies that correspond to provisions of the World Declaration on Higher Education for the Twenty-first Century (World Conference on Higher Education, 1998). The Declaration states that multilingualism should be an integral part of all higher education systems and that intercultural communication is a key requirement for quality higher education in the 21 st century. Such competencies include the ability to speak and write in a foreign language in personal and professional intercultural interaction.

The term communicative competence was introduced by the American ethnolinguist Dell Hymes (1972). He defined communicative competence as the effective use of a language in various social situations. Taking into consideration the complexity of real communication, Hymes distinguished four components of the communicative competence: linguistic, or language, competence (knowledge of vocabulary and grammar); sociolinguistic competence (knowledge and skills necessary for effective use of the language in a social context); discursive competence (ability to comprehend and logically compose separate utterances in accordance with communication goals); strategic competence (knowledge of communicative support strategies and verbal and nonverbal compensatory strategies).

This notion of communicative competence has been revised. Its current interpretation includes two additional subcompetencies: sociocultural competence (a particular degree of social-context acquisition) and pragmatic, or speech, competence (language use for particular functional objectives in accordance with interaction schemes) (Krasilnikova, 2009; Zaytseva, 2004).

Because communicative competence is realized in particular forms of interpersonal interaction the list of subcompetencies might be expanded to include competencies that reflect the psychological characteristics of communication. According to Andreeva's analytical model of communication (2003), communication includes three components: informative, interactive, and perceptive. The informative aspect, or communication as such, consists of information exchange between interlocutors. The interactive aspect amounts to exchanging knowledge and ideas as well as actions. The perceptive aspect implies perception and mutual understanding between partners. In American and European social psychology, the corresponding term for social perception is social cognition (Andreeva, 1999; Bruner, 1974). Similar to Andreeva's $(1999,2003)$ approach to the structure of communication, our approach singles out two additional components of communicative competence: interactive and socioperceptive components. When applied to situations of crosscultural communication socioperceptive competence includes skill in adequately assessing interlocutors' psychological characteristics; awareness of the influence of ethnic stereotypes on the assessment of interlocutors; interpretation of and anticipation of the reasons for interlocutor behavior; and awareness of how interlocutors assess their partners in the communication process. Interactive competence is connected with the coordination of actions in the process of communication. Such coordination is realized through the use of social norms existing in the culture; the ability to manage communicative interaction (to initiate conversation, to stress re- 
spect for the interlocutor) (Sheina, 2010); and the ability to regulate one's emotional state in order to overcome the language barrier.

The linguistic, sociolinguistic, discursive, strategic, sociocultural, and pragmatic components of intercultural communicative competence are studied by students in Russian universities in two courses: foreign language and foreign language in professional activity. The socioperceptive and interactive components are included in the curricula of such courses as psychology and ethnopsychology. In our opinion, communicative competence as a set of all its components might be developed during interactive classes with native speakers of the English language. Such a form of learning has a number of advantages: knowledge of language use in a particular social context can be expanded; particular difficulties in intercultural communication, which could be discussed with a tutor, can be identified; opportunities for pronunciation correction can be provided; motivation for vocabulary enrichment and further language acquisition can be enhanced; and the opportunity to make one's speech more lexically and grammatically authentic can be provided.

However, Russian universities do not offer such classes as a part of the curriculum. As a result, they are provided in the form of nondegree courses. Examples of such courses are the Global Understanding course and the Global Leadership course (East Carolina University, Greenville, South Carolina, USA) offered at the Institute of Psychology, Ural State Pedagogical University (Ekaterinburg, Russia) (Chia, Poe, \& Yang, 2011). The objective of both courses is to enhance students' intercultural communicative competence by means of involvement in synchronous cross-cultural interaction in English with students from all over the world. The syllabus includes culturally relevant topics such as college life, cultural traditions, family, the meaning of life, and stereotypes and prejudices. Each class session includes live discussion in small video groups and one-to-one keyboard chat.

Because the main objective of the courses is development of students' intercultural communicative competence, it is important to understand what factors might decrease the effectiveness of such interactions. Through our observations of students at Ural State Pedagogical University who were participating in the Global Understanding and Global Leadership courses, we discovered that a high level of involvement in active intercultural collaboration influences the use of such collaboration for foreign-language learning and culture acquisition. Because interaction is a two-sided process, a decrease in the involvement of one student will influence the involvement of the partner. We hypothesized that a recipient's involvement might be influenced by certain characteristics of the communicator's utterance: specifically, the richness of their content and their correspondence to language and speech norms.

Compliance with language and speech norms means correct language usage, exact information rendered/perceived, and appropriate use of language units in particular communicative situations (Galskova \& Gez, 2006). A communicator's compliance with language and speech norms plays a crucial role in intercultural interaction; mistakes in foreign-language use and a communicator's unwillingness to correct them might be a so-called risk factor in cross-cultural communication because mistakes imply misunderstanding between interlocutors (Feshkina, 2009). In linguistics, language norms are traditionally understood as the sum total of the stable manifestations of the language system that have been selected and codified 
in public communication - in other words, the sum total of unified language units that are consciously cultivated by the society (Yartseva, 2002). Speech norms are the common use of language units as opposed to their occasional use as codified in dictionaries (Yartseva, 2002). Speech norms regulate the use of particular words and word combinations in speech situations (Vereshchagin, 1969). The corresponding mistakes are distinguished as language mistakes or speech mistakes according to the type of norms. These two language types are considered to have different influences on the effectiveness of cross-cultural communication (Vinogradov, 1983). Language mistakes are thought to be global: they distort the meaning of the utterance. Speech mistakes interfere with authenticity and produce the "incorrectness" effect. To conclude, language and speech mistakes in intercultural communicants' speech might have a different degree of influence on interlocutors' willingness to maintain interaction.

Along with compliance with language and speech norms we also consider informative richness as an important feature of communicators' speech. Informative richness characterizes the content of one's speech, the amount of information that it contains. If speech introduces genuinely new ideas about the subject of conversation, abounds in personal evaluations, and demonstrates the communicator's attitudes, it induces the interlocutor to learn something new (Azimov \& Shchukin, 2009; Ladyzhenskaya \& Mikhalskaya, 1998). For this reason, we hypothesized that the informative richness of a communicator's speech might influence the recipient's willingness to proceed with the interaction. Informative richness is expressed by the category of lexical richness, which is defined by a speaker's vocabulary and manifests itself in the rare use of words devoid of purposeful communicative intention. The lexical richness coefficient is the correlation between lexemes and the total number of words (Ladyzhenskaya \& Mikhalskaya, 1998).

Some ideas about the influence of a communicator's speech characteristics on perception and on the interlocutor's responsive actions have been introduced by researchers in social psychology (Porshnev, 1979). In most cases such research is devoted to nonverbal communication. We suggest that in social psychology verbal communication is viewed as a consciously controlled process: verbal information does not reveal speakers' genuine ideas and intentions if they do not want it to. Some ideas relating to communicants' linguistic and paralinguistic characteristics were introduced by historian and psychologist B. F. Porshnev (1979), who suggested that dialects, speed of speech, and particular sounds of adjacent communities indicate whether an interlocutor represents "the other" and, as a result, whether the communicator should resort to the corresponding interaction strategy. Porshnev also states that deviations in interlocutors' speech might lead to misunderstanding by the recipients. Communicators' unusual characteristics are perceived as "odd" and eventually induce the recipients to protect themselves from unwanted influence. Such characteristics are a different set of phonemes (phonetic misunderstanding), misuse of words (semantic misunderstanding), deviation from grammar structure or logic (syntactic and logical misunderstanding) (Porshnev, 1979).

In studies of the influence of communicants' speech characteristics, the emphasis is usually put on immediate oral communication. However, nowadays written communication is playing a more and more significant role, perhaps because of the 
development of information technologies. In chats or with ICQ (instant messaging software) communication is carried out synchronously in real time, so an addresser's words are perceived by an addressee without any delay. As a result, Internet communication becomes interactive and acquires features of oral communication. Written communication is characterized as an oral conversation whose participants have suddenly started expressing their thoughts in a written form (Lutovinova, 2008). We are interested in such features of written online communication as ignorance of spelling rules, use of jargon, lack of participial clauses and of complex sentences with several relative clauses (Lutovinova, 2008). In oral communication these features might serve as an indicator of illiteracy and lack of education and lead to discontinuance of conversation, whereas in written communication they are normative (Lutovinova, 2008). To summarize, speech deviations have a different influence on oral than on written online communication.

\section{Methods}

The regularities discussed above are applicable to communicators who are native speakers and use the same language in communication. The current study is focused on native-to-nonnative cross-cultural communication carried out in the English language. The research objective was to investigate the influence of the Russian communicants' speech characteristics on the American communicants' willingness to maintain conversations. The study is exploratory because the scientific literature lacks data on cause-and-effect links between one communicant's speech characteristics and the other communicant's willingness to maintain contact in situations of cross-cultural, written, online interaction.

To verify the hypothesis of a cause-and-effect link between the indicated variables, the content-analysis method was used. We analyzed listings of chats involving Russian students from Ural State Pedagogical University (Ekaterinburg) and American students from East Carolina University (Greenville, South Carolina) participating in a global understanding course. In-class chats were carried out during the spring semester of the 2014-2015 academic year and the fall semester of the 2015-2016 academic year. Topics for discussion in the chats corresponded to the course syllabus. Each chat lasted for about 50 minutes.

A number of categories of content analysis were distinguished for each variable included in the hypothesis. The Russian communicants' speech characteristics were described through such categories as mistakes, lexical richness, and lexical scarcity. The category mistakes included five subcategories: language mistakes, speech mistakes, lexical mistakes, grammar mistakes, and spelling mistakes. Differentiation of language and speech mistakes was based on the scientific data on the various influences of these error types on communication (Kleymyonova, 1991). In addition, we distinguished lexical and grammar mistakes according to the language aspects within the normative-error taxonomy. Spelling mistakes were considered a separate group of mistakes and a unique error type. We included such categories as lexical richness and lexical scarcity in the analysis because communication might also be influenced by factors related to the content of the text (informative richness). Comparative analysis of the categories that describe speech violations and informative richness allowed us to determine whether these factors influenced 
communication characteristics equally. The subcategories lexical richness and lexical scarcity reflect the corresponding notions in the scientific literature (Azimov \& Shchukin, 2009; Ladyzhenskaya \& Mikhalskaya, 1998).

Table 1. Categories of content analysis

\begin{tabular}{ll}
\hline Variable & Content-analysis categories \\
\hline Russian communicants' & 1. Mistakes \\
1a. Language mistakes \\
1b. Speech mistakes \\
1c. Lexical mistakes \\
1d. Grammar mistakes \\
1e. Spelling mistakes \\
2. Lexical richness \\
2a. Coefficient of lexical richness \\
2b. Utterances expressing attitudes toward the interlocutors \\
or their words \\
2c. Number of complex sentences \\
2d. Ratio of complex sentences to the sum total of sentences \\
in a micro theme \\
2e. Number of words in the utterances of the micro theme \\
3. Lexical scarcity \\
3a. Repetition of the same word in one sentence \\
3b. Use of conjugates in one sentence
\end{tabular}

The American communicants' willingness to maintain conversations was described through a number of qualitative and quantitative categories. Qualitative categories included the absence/presence of a monosyllabic reply, questions (utterances) expanding on the previous reply, questions (utterances) introducing new information that had not been discussed before, utterances expressing attitudes toward the interlocutors or their words. These subcategories were singled out taking into account the speech-behavior strategies typical of American linguaculture (strategies of communicative support and keep-the-conversation-going strategies) (Kuzmenkova \& Kuzmenkov, 2013). Quantitative categories included the number 
of subthemes touched upon in a micro theme and the number of words in utterances of the micro theme. These subcategories were distinguished according to the manifestations of speech activeness described in the literature on methods of teaching English as a foreign language (Giniatullin, 2008). The complete list of the categories of content analysis is given in Table 1.

\section{Results}

Statistical software SPSS 17.0 was used for mathematical and statistical data processing. Thirteen chats were analyzed in all. The content of each chat was divided into separate micro themes. A micro theme is a complex of questions and answers that are semantically united and thematically separated (Pevzner, 2007). The average number of micro themes in a chat was 6 with a dispersion from 2 (the minimum value) to 10 (the maximum value); 76 micro themes were analyzed in all.

The initial stage of data processing included analysis of different types of mistakes made by the Russian students in written, online chats in English. For each micro theme in a chat the number of language, speech, lexical, grammar, and spelling mistakes was recorded (Table 2).

Table 2. Average number of different types of mistakes made by the Russian students in the micro themes of a chat

\begin{tabular}{lccccc}
\hline & \multicolumn{5}{c}{ Types of mistakes } \\
\cline { 2 - 6 } & Language & Speech & Lexical & Grammar & Spelling \\
\hline $\begin{array}{l}\text { Average number } \\
\text { in a micro theme }\end{array}$ & 2.8 & 0.7 & 0.7 & 2.8 & 1.3 \\
\hline
\end{tabular}

Because the micro themes had different numbers of words, we also calculated the ratio of each error type to the number of words in the utterances of the Russian students. These indicators allowed us to come to more objective conclusions than we otherwise could have about the frequency of the occurrence of each error type. The values of all the indicators were multiplied by 100 so that they can be easily perceived. Thus, Table 3 shows the average number of mistakes of each type that fell in every 100 words in the utterances of the Russian students.

Table 3. Average number of different types of mistakes (per 100 words)

\begin{tabular}{lccccc}
\hline & \multicolumn{5}{c}{ Types of mistakes } \\
\cline { 2 - 6 } & Language & Speech & Lexical & Grammar & Spelling \\
\hline $\begin{array}{l}\text { Average number } \\
\text { in a micro theme } \\
\text { (per 100 words) }\end{array}$ & 6.8 & 1.8 & 1.6 & 7.0 & 2.5 \\
\hline
\end{tabular}

According to Table 3, language and grammar mistakes were numerous in the utterances of the Russian students. Application of the Wilcoxon signed-rank test for 
2 related samples revealed statistically significant differences between the number of language and speech mistakes (significance level $p<0.001$ ), between the number of lexical and grammar mistakes (significance level $p<0.001$ ), and between the number of grammar and spelling mistakes (significance level $p<0.001$ ). In addition, students made fewer lexical mistakes than spelling mistakes (significance level $p=0.02)$.

Initially we suggested that an interlocutor's willingness to maintain a conversation might be influenced not only by the correspondence of speech to language and speech norms but also by the informative richness of the text. The use of descriptive statistics allowed us to come to the following conclusions about the informativerichness indicators of the Russian students' utterances. The lexical richness coefficient varied from 0.58 to 1.00 . The mean value was 0.77 , which is rather high evidence of lexical richness. In $79 \%$ of all the cases the Russian students did not use utterances expressing their attitudes to the interlocutors or their words; in $17 \%$ of the cases they used 1 utterance in a micro theme, and in $1 \%$ of the cases they used 2 utterances in a micro theme. On average students used 3 complex sentences in 2 micro themes. The average ratio of complex sentences to the total number of sentences in a micro theme was 0.3 ; in other words, there were 3 complex sentences in every 10 sentences. In $21 \%$ of the micro themes the students used 1 or more of the same words in each sentence, and they used the same words in each sentence in only $5 \%$ of the micro themes.

Table 4. Correlations between the number of mistakes and indicators of interlocutors' willingness to maintain conversations

\begin{tabular}{|c|c|c|c|c|c|}
\hline \multirow{3}{*}{$\begin{array}{c}\text { Types of } \\
\text { mistakes } \\
\text { made by } \\
\text { the Rus- } \\
\text { sian com- } \\
\text { municants }\end{array}$} & \multicolumn{5}{|c|}{$\begin{array}{l}\text { Indicators of the willingness of the American communicants } \\
\text { to maintain conversations }\end{array}$} \\
\hline & $\begin{array}{c}\text { Questions } \\
\text { (utterances) } \\
\text { expanding } \\
\text { on the pre- } \\
\text { vious reply }\end{array}$ & $\begin{array}{c}\text { Questions } \\
\text { (utterances) } \\
\text { introducing } \\
\text { new infor- } \\
\text { mation }\end{array}$ & $\begin{array}{c}\text { Utterances } \\
\text { expressing } \\
\text { attitudes } \\
\text { toward the } \\
\text { interlocutors } \\
\text { or their words }\end{array}$ & $\begin{array}{c}\text { Number } \\
\text { of subthemes } \\
\text { touched upon } \\
\text { in a micro } \\
\text { theme }\end{array}$ & $\begin{array}{l}\text { Number } \\
\text { of words in } \\
\text { the utterances } \\
\text { of a micro } \\
\text { theme }\end{array}$ \\
\hline & $1 b$ & $1 \mathrm{c}$ & $1 \mathrm{~d}$ & $2 \mathrm{a}$ & $2 b$ \\
\hline $\begin{array}{l}\text { Language } \\
\text { mistakes }\end{array}$ & $\begin{array}{c}\mathbf{0 . 2 6} \\
(p=0.02)\end{array}$ & $\begin{array}{c}\mathbf{0 . 2 2} \\
(p=0.06)\end{array}$ & $\begin{array}{c}\mathbf{0 . 3 6} \\
(p=0.002)\end{array}$ & $\begin{array}{c}0.10 \\
(p=0.38)\end{array}$ & $\begin{array}{c}\mathbf{0 . 4 6} \\
(p=0.000)\end{array}$ \\
\hline $\begin{array}{l}\text { Speech } \\
\text { mistakes }\end{array}$ & $\begin{array}{c}0.18 \\
(p=0.12)\end{array}$ & $\begin{array}{c}0.18 \\
(p=0.12)\end{array}$ & $\begin{array}{c}0.11 \\
(p=0.35)\end{array}$ & $\begin{array}{c}\mathbf{0 . 2 6} \\
(p=0.02)\end{array}$ & $\begin{array}{c}0.16 \\
(p=0.17)\end{array}$ \\
\hline $\begin{array}{l}\text { Lexical } \\
\text { mistakes }\end{array}$ & $\begin{array}{c}0.17 \\
(p=0.14)\end{array}$ & $\begin{array}{c}0.06 \\
(p=0.63)\end{array}$ & $\begin{array}{c}0.16 \\
(p=0.18)\end{array}$ & $\begin{array}{c}0.16 \\
(p=0.17)\end{array}$ & $\begin{array}{c}0.13 \\
(p=0.25)\end{array}$ \\
\hline $\begin{array}{l}\text { Grammar } \\
\text { mistakes }\end{array}$ & $\begin{array}{c}0.27 \\
(p=0.02)\end{array}$ & $\begin{array}{c}\mathbf{0 . 2 4} \\
(p=0.04)\end{array}$ & $\begin{array}{c}\mathbf{0 . 3 3} \\
(p=0.004)\end{array}$ & $\begin{array}{c}0.13 \\
(p=0.25)\end{array}$ & $\begin{array}{c}\mathbf{0 . 4 7} \\
(p=0.000)\end{array}$ \\
\hline $\begin{array}{l}\text { Spelling } \\
\text { mistakes }\end{array}$ & $\begin{array}{c}\mathbf{0 . 6 1} \\
(p=0.00)\end{array}$ & $\begin{array}{c}0.14 \\
(p=0.22)\end{array}$ & $\begin{array}{c}\mathbf{0 . 2 4} \\
(p=0.03)\end{array}$ & $\begin{array}{c}0.11 \\
(p=0.34)\end{array}$ & $\begin{array}{c}\mathbf{0 . 4 0} \\
(p=0.000)\end{array}$ \\
\hline
\end{tabular}

Note. Significant correlations are in bold type. 
We can distinguish the following peculiar features of the American students' willingness to maintain conversations. The American students answered with a monosyllabic reply to their interlocutors' utterances in only $10 \%$ of the micro themes. In $71 \%$ of the micro themes they formulated from 1 to 3 questions expanding on the previous reply; in $51 \%$ of the micro themes they asked from 1 to 2 questions (utterances) that introduced new information that had not been discussed before. In $74 \%$ of the cases the American students did not use utterances expressing their attitudes toward the interlocutors or their words; in $20 \%$ of the cases they used 1 such utterance in a micro theme, and in $6 \%$ of the cases they used 2 or 3 such utterances in a micro theme. In $72 \%$ of all the cases the American students touched upon 1 subtheme in a micro theme, and in $26 \%$ of the cases they touched upon from 2 to 4 subthemes.

To verify the hypothesis about the influence of the Russian communicators' speech peculiarities on the American recipients' willingness to maintain interaction, we carried out correlation analysis. This method allowed us to find significant correlations between variables and to come to conclusions about their influence on one another. To begin, we hypothesized about the correlation between the correspondence of the Russian communicants' speech to language and speech norms and the American communicants' willingness to maintain conversations. The correlation coefficients relating to these variables are given in Table 4.

According to the results of the correlation analysis shown in Table 4, the number of lexical mistakes correlated neither with the qualitative nor with the quantitative indicators of willingness to maintain conversations. In addition, there were weak but statistically significant positive correlations between the number of language, speech, grammar, and spelling mistakes and the qualitative or quantitative indicators of willingness to maintain conversations. The positive values of the correlation coefficients indicate that a more expressed willingness of the American communicants to maintain interaction corresponded to more mistakes by the Russian communicants. This result might be interpreted as support for an interlocutor who is experiencing difficulties in using a foreign language. However, we additionally assumed that positive correlations between mistakes and the willingness to maintain conversations might be caused by the influence of a third variable, which is a common reason for the variability of these two variables (Nasledov, 2008). We thought that perhaps the third variable was the number of words in the Russian communicants' utterances. As additional calculations showed, an increased number of mistakes of all types were found in utterances with more words. In addition, higher qualitative and quantitative indicators of the American communicants' willingness to maintain conversations corresponded to a larger number of words in utterances produced by the Russian communicants.

To verify the hypothesis about the influence of this third variable, we calculated partial correlations between the number of mistakes and the willingness to maintain conversations. As Table 5 shows, different types of mistakes had positive and negative correlations with indicators of the willingness to maintain conversations. An increase in the number of language and grammar mistakes in the Russian communicants' utterances was connected to a decrease in the number of questions (utterances) expanding on the previous reply as well as a decrease in the number of subthemes touched upon in a micro theme. At the same time an increase in the 
number of spelling mistakes was connected to an increase in the number of questions (utterances) expanding on the previous reply. An increase in the number of speech and lexical mistakes was connected to an increase in the number of utterances expressing attitudes toward the interlocutors or their words.

Table 5. Correlations between the number of mistakes and indicators of the American interlocutors' willingness to maintain conversations (the number of words in the Russian communicants' utterances is fixed)

\begin{tabular}{|c|c|c|c|c|c|}
\hline \multirow{3}{*}{$\begin{array}{l}\text { Types of } \\
\text { mistakes } \\
\text { made by } \\
\text { the Rus- } \\
\text { sian com- } \\
\text { municants }\end{array}$} & \multicolumn{5}{|c|}{$\begin{array}{c}\text { Indicators of the willingness of the American communicants } \\
\text { to maintain conversations }\end{array}$} \\
\hline & $\begin{array}{l}\text { Questions } \\
\text { (utterances) } \\
\text { expanding } \\
\text { on the pre- } \\
\text { vious reply }\end{array}$ & $\begin{array}{c}\text { Questions } \\
\text { (utterances) } \\
\text { introducing } \\
\text { new infor- } \\
\text { mation }\end{array}$ & $\begin{array}{c}\text { Utterances } \\
\text { expressing } \\
\text { attitudes } \\
\text { toward the } \\
\text { interlocutors } \\
\text { or their words }\end{array}$ & $\begin{array}{l}\text { Number } \\
\text { of subthemes } \\
\text { touched upon } \\
\text { in a micro } \\
\text { theme }\end{array}$ & $\begin{array}{c}\text { Number } \\
\text { of words in } \\
\text { utterances } \\
\text { of a micro } \\
\text { theme }\end{array}$ \\
\hline & $1 b$ & $1 \mathrm{c}$ & $1 \mathrm{~d}$ & $2 \mathrm{a}$ & $2 b$ \\
\hline $\begin{array}{l}\text { Language } \\
\text { mistakes }\end{array}$ & $\begin{array}{c}-\mathbf{0 . 3 5} \\
(p=0.002)\end{array}$ & $\begin{array}{c}0.03 \\
(p=0.80)\end{array}$ & $\begin{array}{c}0.08 \\
(p=0.49)\end{array}$ & $\begin{array}{c}\mathbf{- 0 . 3 2} \\
(p=0.006)\end{array}$ & $\begin{array}{c}0.14 \\
(p=0.24)\end{array}$ \\
\hline $\begin{array}{l}\text { Speech } \\
\text { mistakes }\end{array}$ & $\begin{array}{c}0.06 \\
(p=0.61)\end{array}$ & $\begin{array}{c}0.05 \\
(p=0.67)\end{array}$ & $\begin{array}{c}\mathbf{0 . 3 0} \\
(p=0.01)\end{array}$ & $\begin{array}{c}0.06 \\
(p=0.60)\end{array}$ & $\begin{array}{c}-0.21 \\
(p=0.065)\end{array}$ \\
\hline $\begin{array}{l}\text { Lexical } \\
\text { mistakes }\end{array}$ & $\begin{array}{c}-0.05 \\
(p=0.70)\end{array}$ & $\begin{array}{c}-0.03 \\
(p=0.79)\end{array}$ & $\begin{array}{c}\mathbf{0 . 2 8} \\
(p=0.01)\end{array}$ & $\begin{array}{c}0.05 \\
(p=0.66)\end{array}$ & $\begin{array}{c}-0.07 \\
(p=0.54)\end{array}$ \\
\hline $\begin{array}{l}\text { Grammar } \\
\text { mistakes }\end{array}$ & $\begin{array}{c}-\mathbf{0 . 3 2} \\
(p=0.005)\end{array}$ & $\begin{array}{c}0.07 \\
(p=0.56)\end{array}$ & $\begin{array}{c}0.12 \\
(p=0.30)\end{array}$ & $\begin{array}{c}-\mathbf{0 . 3 3} \\
(p=0.004)\end{array}$ & $\begin{array}{c}0.08 \\
(p=0.51)\end{array}$ \\
\hline $\begin{array}{l}\text { Spelling } \\
\text { mistakes }\end{array}$ & $\begin{array}{c}\mathbf{0 . 4 9} \\
(p=0.00)\end{array}$ & $\begin{array}{c}0.10 \\
(p=0.38)\end{array}$ & $\begin{array}{c}0.08 \\
(p=0.50)\end{array}$ & $\begin{array}{c}-0.12 \\
(p=0.30)\end{array}$ & $\begin{array}{c}0.22 \\
(p=0.057)\end{array}$ \\
\hline
\end{tabular}

Note. Significant correlations are in bold type.

We also verified the hypothesis about significant statistical correlations between indicators of the informative richness of the Russian communicants' utterances and the American interlocutors' willingness to maintain conversations. As Table 6 shows, the lexical-richness coefficient and the expression of attitudes toward the interlocutors were not connected to the willingness to maintain conversations. An increase in the number of complex sentences in the Russian communicants' utterances corresponded to an increase in the American communicants' questions (utterances) introducing new information. Repetition of the same words in a sentence caused a decrease in the number of questions (utterances) expanding on the previous reply and utterances expressing attitudes toward the interlocutors or their words.

To verify the hypothesis about the influence of the Russian communicators' speech characteristics on the American recipients' willingness to maintain interaction, we used multivariate ANOVA. The willingness to maintain conversations was chosen as a dependent variable because indicators of such willingness are con- 
nected to one another by significant correlations, as is proved by Bartlett's test of sphericity $(p=0.000)$. We chose as factors language and grammar mistakes (the most frequent ones), the number of complex sentences, and the number of words in utterances of a micro theme produced by the Russian students. The rest of indicators were not included in the analysis because they did not have correlations with indicators of the willingness to maintain conversations or because of small variability. Then we distinguished three scales for the factors enumerated above in accordance with the frequency dispersion of their values. The possibility of multivariate ANOVA use is proved by the results of Box's $M$ test, according to which covariance matrices do not vary significantly $(p=0.076)$. The results of the multivariate stage of the dispersion analysis with the use of Pillai's trace are given in Table 7. The table excludes all data about the interrelations between the factors because they are not statistically significant.

Table 6. Correlations between indicators of informative richness and indicators of the American communicants' willingness to maintain conversations

\begin{tabular}{|c|c|c|c|c|c|}
\hline \multirow{3}{*}{$\begin{array}{l}\text { Indicators } \\
\text { of the inform- } \\
\text { ative richness } \\
\text { of utterances } \\
\text { of the Russian } \\
\text { communi- } \\
\text { cants }\end{array}$} & \multicolumn{5}{|c|}{$\begin{array}{l}\text { Indicators of the willingness of the American communicants } \\
\text { to maintain conversations }\end{array}$} \\
\hline & $\begin{array}{c}\text { Questions } \\
\text { (utterances) } \\
\text { expanding on } \\
\text { the previous } \\
\text { reply }\end{array}$ & $\begin{array}{c}\text { Questions } \\
\text { (utterances) } \\
\text { introducing } \\
\text { new infor- } \\
\text { mation }\end{array}$ & $\begin{array}{l}\text { Utterances } \\
\text { expressing } \\
\text { attitudes } \\
\text { toward the } \\
\text { interlocutors } \\
\text { or their words }\end{array}$ & $\begin{array}{l}\text { Number } \\
\text { of subthemes } \\
\text { touched upon } \\
\text { in a micro } \\
\text { theme }\end{array}$ & $\begin{array}{c}\text { Number } \\
\text { of words in } \\
\text { utterances of } \\
\text { a micro theme }\end{array}$ \\
\hline & $1 \mathrm{~b}$ & $1 \mathrm{c}$ & $1 \mathrm{~d}$ & $2 a$ & $2 b$ \\
\hline $\begin{array}{l}\text { Coefficient } \\
\text { of lexical } \\
\text { richness }\end{array}$ & $\begin{array}{c}-0.08 \\
(p=0.52)\end{array}$ & $\begin{array}{c}-0.12 \\
(p=0.32)\end{array}$ & $\begin{array}{c}0.04 \\
(p=0.73)\end{array}$ & $\begin{array}{c}-0.19 \\
(p=0.11)\end{array}$ & $\begin{array}{c}-0.04 \\
(p=0.75)\end{array}$ \\
\hline $\begin{array}{l}\text { Utterances } \\
\text { expressing } \\
\text { attitudes } \\
\text { toward the } \\
\text { interlocutors } \\
\text { or their words }\end{array}$ & $\begin{array}{c}0.12 \\
(p=0.32)\end{array}$ & $\begin{array}{c}0.19 \\
(p=0.10)\end{array}$ & $\begin{array}{c}0.05 \\
(p=0.69)\end{array}$ & $\begin{array}{c}-0.16 \\
(p=0.16)\end{array}$ & $\begin{array}{c}0.10 \\
(p=0.38)\end{array}$ \\
\hline $\begin{array}{l}\text { Number of } \\
\text { complex } \\
\text { sentences }\end{array}$ & $\begin{array}{c}-0.03 \\
(p=0.78)\end{array}$ & $\begin{array}{c}\mathbf{0 . 2 4} \\
(p=0.035)\end{array}$ & $\begin{array}{c}-0.20 \\
(p=0.09)\end{array}$ & $\begin{array}{c}-0.04 \\
(p=0.76)\end{array}$ & $\begin{array}{c}0.07 \\
(p=0.58)\end{array}$ \\
\hline $\begin{array}{l}\text { Repetition } \\
\text { of the same } \\
\text { word in one } \\
\text { sentence }\end{array}$ & $\begin{array}{c}-\mathbf{0 . 3 4} \\
(p= \\
0.003)\end{array}$ & $\begin{array}{c}-0.04 \\
(p=0.73)\end{array}$ & $\begin{array}{c}\mathbf{- 0 . 2 6} \\
(p=0.02)\end{array}$ & $\begin{array}{c}0.20 \\
(p=0.08)\end{array}$ & $\begin{array}{c}-0.06 \\
(p=0.60)\end{array}$ \\
\hline $\begin{array}{l}\text { Number of } \\
\text { words in ut- } \\
\text { terances of a } \\
\text { micro theme }\end{array}$ & $\begin{array}{c}\mathbf{0 . 6 1} \\
(p= \\
0.000)\end{array}$ & $\begin{array}{c}\mathbf{0 . 2 8} \\
(p=0.013)\end{array}$ & $\begin{array}{c}\mathbf{0 . 3 0} \\
(p= \\
0.008)\end{array}$ & $\begin{array}{c}\mathbf{0 . 3 6} \\
(p=0.001)\end{array}$ & $\begin{array}{c}\mathbf{0 . 5 7} \\
(p=0.000)\end{array}$ \\
\hline
\end{tabular}

Note. Significant correlations are in bold type. 
Table 7. Results of multivariate ANOVA

\begin{tabular}{lc}
\hline \multicolumn{1}{c}{ Factor } & Significance \\
\hline Language mistakes & 0.171 \\
Grammar mistakes & 0.044 \\
Number of complex sentences & 0.715 \\
Number of words in utterances of a micro theme & 0.004 \\
\hline
\end{tabular}

Note. Significant correlations are in bold type.

Multivariate ANOVA showed statistically significant results for the influence of the factors grammar mistakes and number of words in utterances of a micro theme $(p<0.05)$ on the willingness to maintain conversations. The results of univariate tests allowed us to determine which components of the multivariate dependent variable were influenced by the indicated factors. An assumption of equal variance should be applied for the univariate stage. According to Levene's test of equal variances, this condition was observed only for these variables: questions (utterances) expanding on the previous reply and number of words in utterances of a micro theme (Table 8).

Table 8. Evaluation of the effects of intergroup factors

\begin{tabular}{llc}
\hline \multicolumn{1}{c}{ Factor } & \multicolumn{1}{c}{ Dependent variables } & Significance \\
\hline Grammar mistakes & $\begin{array}{l}\text { Questions (utterances) expanding on the } \\
\text { previous reply } \\
\text { Number of words in utterances of a micro } \\
\text { theme by the American communicants }\end{array}$ & 0.084 \\
$\begin{array}{l}\text { Number of words in ut- } \\
\text { terances of a micro theme } \\
\text { by the Russian commu- } \\
\text { nicants }\end{array}$ & $\begin{array}{l}\text { Questions (utterances) expanding on the } \\
\text { previous reply } \\
\text { Number of words in utterances of a micro } \\
\text { theme by the American communicants }\end{array}$ & 0.001 \\
\hline
\end{tabular}

Note. Significant correlations are in bold type.

\section{Discussion}

The current research was aimed at investigating a hypothesis about the influence of the Russian communicants' speech characteristics on the American communicants' willingness to maintain interaction in written online communication. Analysis of the results included not only verification of the main hypothesis but also a description of the Russian communicants' speech peculiarities. While analyzing speech characteristics associated with the correspondence of utterances to language and speech norms, we discovered that the most frequent ones were language and grammar mistakes (on average 6.8 and 7.0 mistakes per 100 words respectively) (Table 3). The high frequency of grammar mistakes was confirmed by the results of linguodidactic research (Feshkina, 2009). 
In addition, we carried out a correlation analysis of the variables describing the Russian communicants' speech characteristics and the variables describing the English-speaking communicants' willingness to maintain interaction (Table 5). We discovered that different types of mistakes had multidirectional correlations with the indicators of readiness for dialogue. An increase in language and grammar mistakes in the Russian communicants' utterances was connected to a decrease in such indicators of readiness for dialogue as the number of questions (utterances) expanding on the previous reply and the number of subthemes touched upon in a micro theme. This result corresponds to the scientific data, according to which language and grammar mistakes are considered communicative blunders (Feshkina, 2009; Vereshchagin, 1969; Vinogradov, 1983). Therefore, in comparison with other error types they contribute to a larger extent to risk factors in cross-cultural communication in that they imply misunderstanding between interlocutors (Feshkina, 2009). A decrease in the willingness to maintain a dialogue might be considered a manifestation of misunderstanding one's interlocutor, which interferes with maintaining successful communication.

For other error types the correlation with the indicators of the willingness to maintain interaction was a positive one. An increase in the number of speech and lexical mistakes was connected to an increase in the number of utterances expressing attitudes toward the interlocutors or their words. In linguodidactics and methods of teaching foreign languages, speech mistakes are not considered blunders; they do not distort meaning but produce a certain "accent" (Vereshchagin, 1969; Vinogradov, 1983). For that reason speech and lexical mistakes do not cause misunderstanding. An English-speaking communicant does not have to overcome obstacles to interact. An increase in native speakers' communicative initiatives in this case might be interpreted as the desire to support an interlocutor who is experiencing difficulties in using a foreign language. Different vectors of correlations for various error types might also be viewed as indirect proof of the data on the differential degree of influence of these error types on the communication process (Feshkina, 2009; Vereshchagin, 1969; Vinogradov, 1983).

To verify the main hypothesis, we used multivariate ANOVA. The results of the analysis showed that the American students' willingness to maintain conversations was influenced primarily by two factors: the number of grammar mistakes and the number of words in the utterances of the Russian students. This result proves the significance for maintaining interaction of both aspects of speech utterance: correspondence to language and speech norms (Feshkina, 2009; Vereshchagin, 1969; Vinogradov, 1983) and the informative richness of the text (Azimov \& Shchukin, 2009; Ladyzhenskaya \& Mikhalskaya, 1998).

The results of the correlation analysis described here allow us to claim the multidirectional influence of these two factors on an interlocutor's willingness to maintain a dialogue. The first factor-the number of grammar mistakes in the Russian communicants' utterances-led to a decrease in their American interlocutors' readiness for dialogue. This result might be interpreted according to both linguodidactics and social psychology. As we have already mentioned, grammar mistakes are associated with gross mistakes in the use of parts of speech and their agreement. For this reason an interlocutor might have difficulty comprehending utterances with grammar mistakes; these mistakes in turn might cause failures in commu- 
nication and, as a result, lead to a decrease in an interlocutor's initiative level. Social psychology views communication as closely interrelated to social perception, the perception of one's interlocutor (Andreeva, 2003). If one communicant makes many gross mistakes in speech, then the interlocutor might perceive the communicant as illiterate; this perception can also lead to a decrease in the willingness of the communicant to maintain interaction.

The second factor-the number of words in the utterances of the Russian students-had a reverse influence on interlocutors' willingness to maintain conversations. This factor is a quantitative indicator of the informative richness of utterances. Qualitative indicators of the informative richness of utterances (the coefficient of lexical richness, expression of attitudes toward the interlocutors or their words) proved to be unconnected to the American communicants' willingness to maintain interaction. This result contradicts the scientific data, according to which speech rich in content, which contains a large number of personal evaluations and the communicant's attitude toward the subject of conversation, increases interlocutors' desire to learn more on the topic (Azimov \& Shchukin, 2009; Ladyzhenskaya \& Mikhalskaya, 1998). Perhaps this result is determined by the peculiarities of the intercultural communication situation. We might assume that initially native speakers do not expect high proficiency in the English language from their interlocutors when they belong to another culture. Because informatively rich speech implies relatively high language proficiency, this characteristic is not included in Englishspeaking communicants' expectations. The psychological research describes correlations between subjects' expectations and the result of a perception. Thus, informative richness is not be perceived as a significant characteristic of interlocutors' utterances and does not influence their communicative initiative.

The quantitative aspect of informative richness (the number of words in utterances) in written communication is a visual, easily perceived characteristic. Perhaps for this reason the volume of the Russian students' utterances was a decisive factor that had a significant influence on the American students' willingness to maintain interaction. We might suggest that the volume of utterances produced by a communicator is perceived by the recipient as the communicator's interest in the subject of discussion.

\section{Conclusion}

The results of the current research confirm the hypothesis about the cause-effect connection between a communicant's speech peculiarities and the other communicant's willingness to maintain interaction in situations of intercultural communication. We distinguished two factors that had the most significant influence on the American communicants' readiness for dialogue. The first factor was the number of grammar mistakes in the Russian communicants' utterances. This factor characterized the correspondence of utterances to language and speech norms. The second factor was the number of words in the Russian students' utterances. This factor is the quantitative indicator of the informative richness of utterances. The influence of qualitative characteristics of informative richness proved to be insignificant.

The influence of both factors on the English-speaking communicants' willingness to maintain interaction was multidirectional. The first factor led to a decrease 
in readiness for dialogue whereas the second one caused an increase in such readiness.

To summarize, training participants in intercultural interaction should have two primary objectives: to enhance accuracy in the use of a foreign language and to stimulate speech.

\section{Limitations}

The current research was not aimed at investigating cross-cultural communicative differences. For this reason the qualitative pattern of the research participants corresponds not to comparative-approach requirements but to the particular research objective, which was to study conditions for effective intercultural communication in a learning environment. The sample included Russian and American students of different ages majoring in various subjects. The Russian students demonstrated different levels of English-language proficiency. A factor that limited generalization from the research was the small sample (13 Russian students and 13 American students). Thus it is necessary to verify the hypothesis with a larger sample to more confidently draw conclusions about the stability of the discovered regularities.

To apply the results to a wide range of situations of cross-cultural, written, online communication it is important to note that, in the current research, interaction was carried out as part of an academic course. Such interaction differs from "natural" communication to a certain extent. First, communicants were limited in the choice of discussion points. This requirement was not strictly controlled by a professor, so students were able to discuss any topics they liked. However, they had a learning goal: to uncover similarities and differences in the area that corresponded to the topic of the class. Second, participants had to maintain interaction during the whole class (about 50 minutes). In natural interaction a communicant can interrupt communication at any time-for example, if the interlocutor is perceived as not very interesting. Therefore, we can conclude that the results of the current research are applicable to written online communication between Russian and American students in a learning environment.

\section{References}

Andreeva, G. M. (1999). K problematike psihologii socialnogo poznaniya [To the problem of social perception]. Mir psilkologii [World of Psychology], 3, 15-23.

Andreeva, G. M. (2003). Sotsialnaya psikhologiya [Social psychology]. Moscow: Aspekt Press.

Azimov, E. G., \& Shchukin, A. N. (2009). Noviy slovar metodicheskikh terminov i poniatiy (teoriya i praktika obucheniia yazykam) [A new dictionary of terms and notions of the methods of teaching]. Moscow: IKAR.

Bruner, J. (1974). Beyond the information given: Studies in the psychology of knowing. London: Allen \& Unwin.

Chia, R., Poe, E., \& Yang, B. (2011). History of Global Partners in Education. Global Partners in Education Journal, 1, 3-7. Retrieved from http://www.gpejournal.org/index.php/GPEJ/ article/view/11/7

Feshkina, I. A. (2009). Faktor riska v usloviyakh mezhkulturnoyi kommunikatcii [The risk factor in intercultural communication] (Unpublished doctoral dissertation). Saratov, Russia: Saratov Chernyshevsky State University. 
Galskova, N. D., \& Gez, N. I. (2006). Teoriya obucheniya inostrannym yazykam. Lingvodidaktika $i$ metodika [The theory of teaching foreign languages. Lingvodidactics and methods of teaching]. Moscow: Akademiya.

Giniatullin, I. A. (2008, December). Rechevaia aktivnost kak obekt razvitiia pri ovladenii inostrannym iazykom [Speech activeness as an object of development during language acquisition]. In Samostoiatelnaya uchebnaya deiatelnost $v$ razlichnykh formakh professionalnogo yazykovogo obrazovaniia [Self-education in various forms of professional language education: Materials of the Second Regional Scientific and Practical Conference] (vol. 2, pp. 18-28). Ekaterinburg, Russia.

Hymes, D. (1972). On communicative competence. In J. B. Pride \& J. Holmes (Eds.), Sociolinguistics: Selected readings (pp. 269-293). New York: Harmondsworth.

Kleymyonova, T. M. (1991). Differentcirovannaya korrektciya oshibok kak metodicheskiy priem aktivizatcii rechevoi deiatelnosti studentov (na materiale obucheniia angliiskomu yazyku $v$ neiazykovovm vuze) [Differentiated error correction as a teaching method for activating students' speech activity (exemplified by teaching English in a nonlanguage university)]. (Unpublished doctoral dissertation). Moscow: Research Institute of General Secondary Education of USSR Academy of Pedagogical Sciences.

Krasilnikova, E. V. (2009). Inoiazychnaia kommunikativnaya kompetentciya v issledovaniyakh otechestvennykh i zarubezhnykh uchenykh [Communicative competence in a foreign language in the research of scientists in Russia and abroad]. Yaroslavskiy Pedagogicheskiy Vestnik [Yaroslavl Educational Bulletin], 1, 179-184.

Kuzmenkova, Yu. B., \& Kuzmenkov, A. P. (2013). Angliiskiy yazyk dlya mezhkulturnogo obshcheniya [The English language for intercultural communication: ABCs of effective communication]. Moscow: Moscow University Press.

Ladyzhenskaya, T. A., \& Mikhalskaya, A. K. (1998). Pedagogicheskoe rechevedeniye. Slovar-spravochnik [Pedagogical speech science: Dictionary and reference book] (3rd ed.). Moscow: Flinta, Nauka.

Lutovinova, O. V. (2008). Internet kak novaya «ustno-pismennaya» sistema kommunikatcii [The Internet as a new "oral and written" system of communication]. Izvestiya Rossiyskogo Gosudarstvennogo Pedagogicheskogo Universiteta im. A. I. Gertsena [Gertsen Russian State Pedagogical University Bulletin], 71, 58-65.

Nasledov, A. D. (2008). Matematicheskie metody psikhologicheskogo issledovaniia. Analiz i interpretatciia dannykh [Mathematical methods of psychological research: The analysis and interpretation of data]. A textbook (3rd ed.). St. Petersburg: Rech.

Pevzner, A. S. (2007). Spetcifika dialoga v praktike regionalnykh kommercheskikh radiostantcii [Peculiarities of dialogue in the practice of regional commercial radio stations]. Vestnik Chelyabinskogo Gosudarstvennogo Universiteta [Chelyabinsk State University Bulletin], 8, 73-79.

Porshnev, B. F. (1979). Sotsialnaya psikhologiya $i$ istoriya [Social psychology and history] (2nd ed.). Moscow: Nauka.

Sheina, I. M. (2010). Mezhkulturnaia kommunikatciia kak proiavlenie lingvisticheskogo i kulturnogo opyta [Intercultural communication as manifestation of linguistic and cultural experience] (Unpublished doctoral dissertation). Ryazan, Russia: Ryazan State University.

Vereshchagin, E. M. (1969). Voprosy teorii rechi i metodika prepodavaniya inostrannykh yazykov [Issues in speech theory and methods of foreign-language teaching]. Moscow: Moscow University Press.

Vinogradov, A. V. (1983). Stratifikatciya normy, interferentciya i obuchenie yazyku [Stratification of the norm, interpretation, and teaching language]. In Lingvisticheskie osnovy prepodavaniya yazyka [The linguistic basis of teaching language] (pp. 44-65). Moscow: Nauka. 
World Conference on Higher Education. (1998). World declaration on higher education for the twenty-first century: Vision and action, Paris, 9 October 1998. Retrieved from http://www. unesco.org/education/educprog/wche/declaration_eng.htm

Yartseva, V. N. (2002). Lingvisticheskiy entciklopedicheskiy slovar [Linguistic encyclopedic dictionary]. Moscow: Bolshaya Rossiyskaya Entsiklopediya.

Zaytseva, S. E. (2004). Printcipy dostupnosti i kommunikativnoi napravlennosti obucheniia studentov $v$ usloviiakh primeneniia infokommunikatcionnykh tekhnologii [Principles of availability and communicative orientation for teaching students by using infocommunicative technologies] (Unpublished doctoral dissertation). Stavropol, Russia: Stavropol State University.

Original manuscript received November 11, 2015

Revised manuscript accepted January 25, 2016

First published online June 30, 2016 